\begin{tabular}{cc}
\hline \hline \\
\hline \hline 1
\end{tabular}$\quad \begin{gathered}\text { International Journal of Current Research } \\
\text { and Academic Review } \\
\text { ISSN: 2347-3215 (Online) Volume 7 Number 4 (April-2019) } \\
\text { Journal homepage: http://www.ijcrar.com }\end{gathered}$

doi: https://doi.org/10.20546/ijcrar.2019.704.009

\title{
Difficulties of Female Students in Classroom Participation in English at Areka Preparatory School, Wolaita Zone, Southern Ethiopia, 2019
}

\author{
Addisu Bogale Shago*
}

Department of English Language and Literature, College of Social Science and Humanities, Wolaita Sodo University

*Corresponding author

\begin{abstract}
Lee (2005) says participation usually means students speaking in classroom such as answering teacher's questions or other students' questions, asking questions to get the better explanation and clarification. As long as English language is very important in Ethiopian high school students' academic performance, due consideration should be given to female students in target subject matter. A number of female students in high school of target research area were very low compared with male counterparts, which initiated the researcher to conduct present research in targeted area. So, the study enables to address problems to different concerned bodies and helps female students to enhance their classroom participation in English as well as outside the classroom. The objective the study was 'Difficulties of Female Students in Classroom Participation in English at Areka Preparatory School, Wolaita Zone, Southern Ethiopia.' Mixed methods i.e. quantitative and qualitative research designs were used. 70 participants were selected using simple random sampling. 2 English teachers were selected purposively. Self administered questionnaire and interview were employed to collect data. Quantitative data were analyzed using SPSS and qualitative data were supported the quantitative one. As the result shown the largest number $28(40 \%)$ of respondents were not confident in classroom participation. Most of respondents, $34(48.6 \%)$ were not participated in mixed sex group in English classroom. 27 (38\%) responded guidance and counseling were highly helped them. 36 $(51.5 \%)$ were strongly agreed that female students were affected by fear. Most of the time, English teachers were directed questions to male students than female students in the classroom as it was represented by large number, i.e. 37 (53\%). Significant large numbers of respondents, $23(32.8 \%)$ socio-cultural factors were not affected female students' classroom participation in English. $30(42.8 \%)$ said they had no interest in English subject matter so that they were not interacted in English. Thus, the extents of female students were low. They were less likely took part in mixed-sex group arrangement. Guidance and counseling played great role in their participation. English teachers were rarely encouraged girls. It is better if much consideration should be given to female students' involvement in education in general and classroom participation in English in particular. English teachers should give equal chance to female students as of male counter parts while asking question in the classroom. They also should frequently encourage female students by giving advice, tutoring them in same sex arrangement, giving awareness, etc. to promote their confidence to interact in the classroom.
\end{abstract}

\section{Article Info}

Accepted: 04 March 2019

Available Online: 20 April 2019

\section{Keywords}

Classroom participation; Female students. 


\section{Introduction}

Lee (2005) says participation usually means students speaking in classroom such as answering teacher's questions or other students' questions, asking questions to get the better explanation and clarification. He added that making comments and joining discussions by sharing their opinions, thoughts, and ideas are also considered as students' participation in classroom. Besides, Tsiu (1998) indicates classroom interaction as the students' participation in classroom.

He adds that classroom participation requires students' to speak and interact in the classrooms to indicate that they are actually learning and paying attention. An important form of involvement is student's participation in classroom interaction by seeking and giving information, expressing thoughts, feeling and ideas, asking and answering questions and participating in discussion (Tsiu, 1998).

Moreover, as to Welty to facilitate whole-class discussion, the teacher might request a U-shaped case classroom, move chairs into a horseshoe or circle, or otherwise adjust space so that students can address each other without passing all commentary through the instructor (1989).

Regarding students strategies of participation, scholars such as (Bean, 1996, pp. 107-108, McKeachie (1986, p. 37 and Davis, 1993, p. 79) suggested problem areas and overcoming problems of students' classroom participation.

To grade classroom participation fairly, the instructor needs to create an environment that gives all students an opportunity to participate. But for professors who use whole-class discussion with limited prompting from the teacher, they need other means of inviting the silent to speak and quieting the extroverts. So above mentioned scholars offer several strategies.

\section{Strategy 1}

Create Activities in which participants report on homework already prepared: Often, quiet people are more comfortable speaking in class if they can prepare ahead of time. Co-author John Bean assigns "guided journals" in which students write a one-page journal entry prior to each class in response to a question passed out in advance (Bean, 1996, pp. 107-108). A student can be called on to summarize what he or she wrote in a journal, thus reducing the anxiety of having to respond to a question extemporaneously.

Strategy 2: Increase Wait Time: Another strategy of leveling the playing field in classroom participation is to pose a question and then to enforce a minute or so of silence for students to structure their reply. After a minute or so, the teachers ask for volunteers or calls on a selected student.

Strategy 3: Use a "Card System" for Shy Students: Teachers might also consider using "comment cards" for shy students. Students who are reluctant to participate in class might be allowed to turn in $3 \times 5$ cards bearing their responses to questions posed during discussion.

Strategy 4: Develop Techniques for Quieting Discussion Dominators: A number of writers have addressed the problem of the overly talkative or rambling student. McKeachie (1986, p. 37), for example, suggests that professors assign one or two students to act as "observers" with the duty of reporting to the class the extent to which participation is evenly distributed. The teacher/instructor might even assign a discussion monopolizer to be an observer for a day (Davis, 1993, p. 79) for a helpful summary of strategies for quieting discussion dominators

Strategy 5: Coach Problematic Students and Reward Progress: Teachers can also invite students who are not successfully participating in class to an office conference where the instructor can speak honestly about the problem and listen to students' perspectives and concerns. Through supportive coaching, students may begin to make small steps toward progress steps which the instructor can visibly reward.

Furthermore, in this regard a number of studies indicated that in Ethiopia female students lag behind academically compared with male students for different reasons (Tsige, 1989). From this we can see that they have low participation in classroom activities such as pair work, group work and so on and they have also no balanced opportunities in education.

Access to education is a key to women's equal participation in every area of activities from family decision making to economic and political life (Tirufat 1998: 148). From this we can notice that their ignorance in education is likely to discriminate females from participating in the development of their country. There was an old belief that people relate to women: women 
were seen as being inferior, designed only for house-hold activities and low-skilled responsibilities; hover, reality it is not. In relation to this, Seyoum (1986: 11) says the involvement of females in house-hold activities and stereotyped beliefs are some of the main factors that contribute to their low participation in the other areas of life.

Different researchers in second (foreign) language learning reveal that learners should be active participants in classroom activities to be in the best position to learn a language (Johnson 1994 and Spolsky 1989). Learning second language (in this case English) is very important in Ethiopia because it a medium of instruction from primary to tertiary levels. Therefore, in English classroom interaction students' active participation is very important to learn the language better and better in other subject matters. However, females are dominated by male counterparts in such communicates activities where they seem to interact less and speak less so that they gain less participative ability.

\section{Statement of the problem}

As long as English language is very important in Ethiopian high school students' academic performance, due consideration should be given to female students in target subject matter. Because of different factors such as shyness, their expectation that they are inferior to males and other related problems, female students may contribute to the low involvement in English classroom interaction. On the other hand, teachers do not treat male and female students equally. Sunderland explains these situations as:

Teachers treat male and female students differently. They tend to favor male students by paying attention more, encouraging more, giving instructional contact more than female students (1994: 9)

As far as researchers' observation in classroom is concerned, a number of female students in high school of target research area were very low compared with male counterparts. This in turn may contribute to the low participation of female students in their academic performance in general and English classroom interaction in particular. Furthermore, as some female students who have personal contact with the researcher assured that other factors contributing them to less involvement in English language in the classroom are their family background and less commitment to acquire communicative competence. Above mentioned problems initiated the researcher to conduct this research at Areka Preparatory school in Wolaita Zone, Sothern part of Ethiopia.

\section{Objective of the Study}

\section{Genera Objective of the Study}

The general objective of the study is Difficulties of Female Students in Classroom Participation in English at Areka Preparatory School, Wolaita Zone, Southern Ethiopia.

\section{Specific Objectives of the Study}

The following are the specific objectives of the study.

* To distinguish the extent of female students' participation in English classroom in different group arrangements: male-dominated, femaledominated and same sex group.

* To find out whether the female students' family background affect their participation in English classroom or not

* To see what extent English language teachers provide opportunity to both male and female students in English classroom.

* To examine female students' perception about themselves regarding classroom participation in English.

\section{Significance of the Study}

The study has the following significances:

It enables to address problems to different concerned bodies like policy makers, syllabus designers and other to incorporate their ideas using the target research findings and recommendations forwarded by the researcher. It paves the way to researchers to conduct further researches in the same area which means it helps researches as a reference material. It also helps female students to enhance their classroom participation in English as well as outside the classroom. Besides, it is important to take measures and helps to employ appropriate strategies to increase the female students' participation in ELF classroom in target school. It provides female students to develop their English language proficiency in and outside the classroom and it promotes them to achieve good result in university entrance examination. 


\section{Scope of the study}

The target area of the research is confined to Areka Preparatory School grade 11 female students. Areka Preparatory School is found in Wolaita Zone which is found in Southern Ethiopia. Wolayta Zone has 16 woredas (Abela Abaya, Bayra Koisha, Kawo Koisha and Hobicha are newly structured woredas) and 6 city administrations (Gesuba, Gununo and Humbo Tebela are newly structured city administrations). The Zone has an area of approximately 438,370 hectares, and an estimated population of $1,750,830$. The targeted school is located about $300 \mathrm{~km}$ south of Addis Ababa across Hosana. As per the report of Wolaita zone education department, there were about 26 preparatory schools among which Areka preparatory school is selected purposively aiming to conduct research.

\section{Materials and Methods}

\section{Research Design}

Kumar (1999) stated that a research design is a procedural plan that is adopted by researchers to answer questions objectively, accurately, economically and with validity. The researcher used both qualitative and quantitative research design. Let's see the theoretical background of these designs. According to scholars (Denzin and Lincoln, 2000) a study based upon a qualitative process of enquiry has the goal of understanding a social or human problem from multiple perspectives Thus, qualitative researchers deploy a wide range of inter connected interpretive practices, hoping always to get a better understanding of the subject matter at hand. Additionally, they also explained that qualitative research is conducted in a natural setting and involves a process of building a complex and holistic picture of the phenomenon of interest as well as being inductive in nature.

On the other, quantitative is based on testing a theory, measured with numbers, and analyses using statistical techniques and it particularly emphasizes objectivity (Smith et al., 1979). Besides, Fraenkel and Wallen (2003) argued that the goal of quantitative methods is to determine whether the predictive generalizations of a theory hold true. Thus, quantitative research is more concerned with issues of how much, how well, or to whom that particular issue applies. Kerlinger and Lee (2000) also explained that quantitative research is deductive in nature, and that researchers make inferences based on direct observations with the primary goal to describe cause and effect.
Therefore, a researcher also delves into the issues of interest in depth and detail. Mixed methods combine quantitative and qualitative research.

\section{Sample selection}

The method of sample selection was simple random sampling (SRS) technique. It is a method of selection of a sample comprising of $\mathbf{n}$ number of sampling units out of the population having $\mathbf{N}$ number of sampling units such that every sampling unit has an equal chance of being chosen. In the current study, the sample members who were selected had relationship with the researcher, he has sufficient and relevant work experience, active involvement in several partnerships like community serves as well as proven research background and understanding of raw data concerning destinations in selected school. Therefore, the participants of this study were 70 female students out of 120 students from 4 sections. Besides, two English teachers were selected purposively for the interview because could find them and easily communicate (Table 1).

\section{Tools of data collection}

For the purpose of this research, both questionnaire and interview were used to collect data. A questionnaire is a data collection instrument consists of a series of questions and other prompts to gather information from respondents. The researcher administered two types of questionnaires: closed-ended and open-ended. The closed-ended questionnaire consisted 15 items distributed to respondents. On the other hand, 2 openended questions were prepared to the same respondents. For teacher interviewee, 5 structured interview questions were prepared based on the objectives of the study. Both questionnaire and interview question items for female students and teacher respondents were prepared in English.

\section{Procedures of data collection}

Meetings were held during February 2019 with the school principal, vice principals, teacher and some selected students on issue of how to manage the data gathering situation and for the betterment of achieving the objective of the study. Making discussing with those individuals was because of to gain acceptance in the research process. More specifically, the researcher came in touch with and asked them to participate in the research after explaining the nature and the scope of the study. The respondents were willing to participate in the 
research and the interviews. The discussions took place at the offices of the school principal of Areka preparatory school and lasted approximately 30-40 minutes.

\section{Process of data analysis}

According to Moore and McCabe (2005), this is the type of research whereby data gathered is categorized in themes and sub-themes to be able to be comparable. A main advantage of content analysis is that it helps in data collected being reduced and simplified, while at the same time producing results that may then measured using quantitative techniques. Moreover, content analysis gives the ability to researchers to structure the qualitative data collected in a way that satisfies the accomplishment of research objectives. However, human error may be involved in this analysis. Besides, the data gathered through questionnaire were tabulated using frequency measured in percentage. And conclusions were drawn based on findings and recommendations were forwarded based on conclusion. Quantitative data were tabulated using likert scales such as strongly agree, agree, undecided, disagree and strongly disagree and then analyzed using SPSS. Each scale was measured by using percentage.

\section{Ethical considerations}

The current study was subject to certain ethical issues. The researcher is committed to abide by FFP rules. To mean avoiding research misconduct meaning that Fabrication, Falsification, or Plagiarism (FFP) in proposing, performing, or reviewing research, or in reporting research results. Fabrication is making up data or results and recording or reporting them. Falsification is manipulating research materials, equipment, or processes, or changing or omitting data or results such that the research is not accurately represented in the research record. Plagiarism is the appropriation of another person's ideas, processes, results, or words without giving appropriate credit. Therefore, the researcher ensured that the work is new and original research and researcher was allowed participants to be involved in giving any information willingly.

\section{Results and Discussions}

\section{Analysis of data collected via questionnaire (closed- ended)}

This chapter deals with presenting, discussing and interpreting data gathered from respondents via questionnaire and structured interview.
In relation to item number 1 , the largest number 28 (40\%) of respondents were disagreed which means the female students were not confident in classroom participation. The next largest number i.e. 24 (34.2\%) responded as they were strongly disagreed that means they were not participated in English classroom. 7 (10\%) participants responded that they agreed that they were participated confidently in ELF classroom. Besides, the least number of participants i.e. 6 (8.6\%) and $5(7.2 \%)$ said that they were strongly disagreed and reluctant or undecided respectively for the given question item. From this we can see that female students were not participated confidently in English classroom as their male counterparts performed.

Regarding item number 2 in table 2 that 30 (42.9\%) of female student respondents agreed that they were good at interaction being in the same group. At the same time 15 (21.5\%) of participants answered that they were strongly disagreed i.e. they were not highly interacted in the classroom in English lessons. Besides, 12 (17.1\%) female students agreed their interaction was high if they were being in same group. Moreover, 9 (12.9\%) and 4 $(5.7 \%)$ reacted as undecided and disagreed respectively.

As this result shown that female students performed better in their interaction when they were in same sex group in English classroom. Even though this result shown females' high level of participation, not least numbers of female students i.e. $21.5 \%$ were responded to this question item as they were strongly disagreed to high participation in the classroom.

As regards item 3 in the table 2 indicated that most of respondents, $34(48.6 \%)$ were disagreed meaning that they were not participated in mixed sex group in English classroom. Similar number of participants, 13 (18.6\%) shown agreement and disagreement for question item 3 which was to check whether female students were highly participated or not. $7(10 \%)$ and $3(4.2 \%)$ respondents reacted they were strongly disagreed and undecided correspondingly.

From this we can see that female students were tended to be dominated by male students in English classroom in mixed sex group arrangement.

A large number of female respondents that means 27 (38\%) were agreed which means guidance and counseling were helped them to promote their participation in the classroom in ELF classes. In addition to this, $14(20 \%)$ answered that they were strongly 
agreed to the question item 4 . In this regards, 13 (18.6\%) of respondents were disagreed, $11(15.7 \%)$ respondents were undecided and the least number of respondents, 5 $(7.2 \%)$ were strongly disagreed to the given item.

From this we can conclude that to promote female students' classroom participation in English, guidance and counseling had great role.

Concerning item number 5, huge number of female participants, $22(31.4 \%)$ were disagreed i.e. they were not equally involved in English classroom with male students. Furthermore, next largest number of participants, $17(24.3 \%)$ said that they were strongly disagreed. $12(17.1 \%)$ female students were agreed to the question item 5, meaning that they were equally participated in the classroom. Lastly, 4 (5.7\%) students said that they were strongly agreed in their equal participation in English classroom.

With reference to question number 6, 25 (35.7\%) participants were strongly disagreed that means they were not accepted their academic weaknesses as being femaleness. In addition, the second largest number of respondents disagreed that they were not accepted their academic weaknesses of their gender. Although the respondents had not accept the idea of item number 6, significant number i.e. $16(22.9 \%)$ participants were agreed to the question. The least numbers, $6(8.6 \%)$ and $4(5.7 \%)$ respondents were remained undecided and strongly disagreed with the given idea.

Regarding item 7 in the table 2, significant number of target students, $18(25.7 \%)$ were remained undecided which shown they were not pessimistic over their education that was not led them to low participation. Likewise, $17(27.1 \%)$ were disagreed with the idea of pessimism in education. $12(17.1 \%)$ respondents were strongly agreed that they were pessimistic in education in general and participated in low level in particular. 13 $(18.6 \%)$ were strongly disagreed and 10 (14.3\%) participants were disagreed meaning that they were not pessimistic in education, which had no contribution in classroom participation. From this we can decide that female students were not pessimistic in education if they were encouraged to learn effectively.

To see whether English teachers frequently encouraged female students or nor, the significant number, 29 (41.4\%) of participants were disagreed i.e. teachers neither were nor frequently encouraged, however; 18 $(25.7 \%)$ respondents were agreed. $11 \quad(15.7 \%)$ participants were undecided. Only 10 (14.5\%) were strongly agreed with the question item number 8 . The least number of respondents were strongly disagreed.

From the above discussion, we can firmly conclude that teacher were not frequently encouraged female students in English classroom to enhance their involvement.

On the other hand, for item number 9 in the table 2 , enormous number of female respondents meaning that 30 $(42.9 \%)$ were agreed that teachers were encouraged them sometimes in the classroom in English lesson. Moreover, next largest number of participants 21 (30\%) were strongly agreed that they were sometimes encouraged by teachers in the classroom. But 13 (18.6\%) target students were undecided; they had no idea to say on it. Finally, 5 (7.1\%) and $2(1.4 \%)$ respectively responded as disagreed and strongly disagreed.

Regarding fear of teachers in the classroom under question item 10, $36(51.5 \%)$ responded they were strongly agreed and $18(25.7 \%)$ were agreed. This shown that those female students were affected by fear of their English teachers in the classroom. However, 7(10\%), 5 $(7.1 \%)$ and $4(5.7 \%)$ participants reacted they were disagreed, undecided and strongly disagreed respectively.

We can conclude from this that female students accompanied fear in the classroom in English lesson. This again shown that English teachers' were less likely encouraged female students, as a result the target students performed less in their interaction.

Most of the time, English teachers were directed questions to male students than female students in the classroom as it was represented by large number of participants i.e. 37 (53\%). 14 (20\%) female student participants were disagreed. Besides, 12 (17.1\%) respondents were agreed and the remaining least number of respondents, $4(5.7 \%)$ and $3(4.2 \%)$ were undecided and strongly disagreed correspondingly. Thus, it can be depicted as more chances were given to male students than female students in English classroom.

The largest number $29(41.5 \%)$ of female students disagreed and 21 (30\%) were strongly disagreed concerning the chance given to their interaction. Nevertheless, 15 (21.4\%) respondents were undecided to the question. 4 (5.7\%) were also strongly agreed and the least number of them, 1 (1.4\%) were agreed. 
Therefore, English teachers were not focused in directing questions to female students in the classroom during English lesson rather than male counterparts.

Concerning whether family background affected female students English classroom participation or not, 33 $(47 \%)$ of them agreed but insignificant number, 17 $(12.3 \%)$ of them were disagreed with this idea. Similar number of participants, 9 (12.9\%) were responded that they were strongly agreed and strongly disagreed.

From this we can generalize that their family backgrounds most likely affected their involvement in the classroom in English lesson.

Significant large numbers of respondents 23 (32.8\%) were strongly disagreed i.e. socio-cultural factors were not affected female students' classroom participation in English. The next largest number of participants, 20 $(28.6 \%)$ were undecided. Furthermore, 18 (25.7\%) female respondents were disagreed. However, the least number of them were strongly agreed and agreed regarding socio-cultural factors. Thus, we can see that this factor had not affected female students' participation in the classroom.

Lastly, huge number of participants 30 (42.8\%) agreed that they had no interest in English subject matter so that they were not interacted in English. On the other hand, $14(20 \%)$ respondents said they were disagreed. 10 $(14.3 \%)$ were strongly agreed that they had interest in English. The least number of participants 9 (12.9\%) and $7(10 \%)$ respectively said that they were undecided and strongly disagreed.

\section{Analysis of open-ended questions}

To what extent do you participate in English in male dominated classroom? Explain in detail.

As female students explained in detail, most of the time, they did not take part in English classroom especially when they were arranged in mixed sex group in the classroom. Even they didn't like to sit beside the male students because they were not comfortable if they did so. But they were comfortable to sit with same sex group that avoided the fear of making mistakes, enhanced confidence; generally they were inclined to advise their female friends when they were in confusion with something else in English. For example, when English teachers called them to teach tutorial classes, as most of them explained that they were freely participated in the classroom without feeling discomfort unlike that of being in mixed sex group arrangement.

When English teachers arrange same sex group to tutorial classes, as they explained most of female students were participated freely, they said they minimized fear of making mistakes, increase confidence to speak in English in the classroom. This idea was similar to teacher respondents in interview.

Therefore, from this we can confidently conclude that their participation was very low if they were arranged in mixed sex groups in English lessons in the classroom. Besides, they were dominated by male students who were tended to better participate in English classes than female ones.

To what extent do your perception about yourself promoted your participation English classroom? Explain in detail.

Large numbers of respondents answered it as its subjectivity i.e. most of them said they had positive perception but some of them had negative perception about themselves. However, enormous number of female students had perceived positively which promoted them better in the classroom. They had given value to themselves, tried to avoid shyness, fear of peers, teachers, etc. as they were explained.

\section{Analysis of teachers' interview}

Q1. Do you think socio-cultural factors are obstacles for female students' classroom participation in English? If so how does it affect their participation in English classroom?

Ans. Yes. Because of such factors they were even reluctant in taking part in pair as group discussions. As well as my knowledge is concerned they were not participating in speaking like inducing themselves, introducing other people, describing things and person as well. Such problems were the cause of cultural and social factors. For example, as I am female I know that how such factors affected me in during mu education in the university when I was studying at Dilla University. Furthermore, she has work load at home so she has no ample chance to study, to practice, etc. as a result she has no confidence when she doesn't study. Therefore, she was ashamed of making mistakes, has no interest in speaking in English and so on that made her not to participate in the classroom. Besides, culturally females 
are expected to carry out home activities than male counter parts. This assumption also negatively contributed to low classroom participation.

Q2. Do you encourage female students to participate in the classroom in English? If yes how do you do so?

Ans. Ammm Not often, but sometimes I encourage them by asking different questions. Because they are not interested interacting in English like boys, who were stronger or better than girls performed. To do so, I give special support to female students by giving them tutorial classes additionally because they were not equally involved in classroom as male students. If they were supported by teachers arranging in same sex group, they would have performed better than ever before. So, all subject teachers should support them independently until they become confident.

Q3. Do you agree the religious factor affects female students' classroom participation in English? If you agree, in what condition does it affect their participation?

Ans. I disagree with this idea because I believe that if any female students who are member of any religions are encouraged nothing will block them to participate (become cleaver) in English in particular as well as other subjects as whole. Therefore, religious has no influence on female student' education in general and classroom participation in particular.

Q4. Do you agree guidance and counseling in the school has role in female students classroom participation?

Ans. Yes absolutely. It has the greatest role in their participation because if they are psychologically prepared to participate, they do not being ashamed of, shy, fear of making mistakes, fear of male students, teachers and so on. For example, some female students who have knowledge were reluctant in speaking in English. But if they are getting consultancy service in that structure they will start participation in pair, group etc. in the classroom.

Q5. Explain how family's literacy and illiteracy affect female students' classroom participation in English.

Ans. Yeah their family background contributed to their participation. For instance, as my observation in the classroom and the information about such students at my hand, female students who come from illiterate family have less performance in English language score/result not only speaking but also other kind macro-skills and micro skills of language. However, those female students whose families have good literacy participate better than that of illiterate ones. Those families encouraged them buying reference books, encouraged to go to tutorial classes, reduced home activities, given attention to their learning, etc. They were giving chance to their daughters to study and to do her home work. They were also followed their learning.

From this it can be concluded that cultural and social factors negatively influenced their participation in the classroom. So, that they scored low result in English subject matter. English teachers were not gave due attention to female students because they were not wanted to impose female students to participate rather teachers took remedial action in giving tutorial classes independently to encourage girl pupils in the school. Religion had no effect on female students' participation and also guidance and counseling had influential role in female students' classroom participation. Their families being literate or illiterate contributed in their classroom involvement in English to mean that literate one contributed positively and the vise-versa is true.

\section{Summary of major findings, conclusion and recommendations}

\section{Summary of major findings}

Based on the analysis of data, the major findings were summarized as follows.

The largest number $28(40 \%)$ of respondents were disagreed and $24(34.2 \%)$ responded that were strongly disagreed which shown the female students were not confident in classroom participation. Enormous number of respondents, $30(42.9 \%)$ were good at interaction being in the same group. At the same time 15 (21.5\%) were not highly interacted in the classroom in English lessons. As this result shown that female students performed better in their interaction when they were in same sex group in English classroom. Most of respondents, $34(48.6 \%)$ were disagreed meaning that they were not participated in mixed sex group in English classroom. It can be seen that female students were tended to be dominated by male students in English classroom in mixed sex group arrangement. Guidance and counseling were helped them to promote their participation in the classroom in ELF classes as 27 (38\%) were agreed. To promote female students' classroom participation in English, guidance and counseling had great role. $22(31.4 \%)$ were disagreed i.e. they were not 
equally involved in English classroom with male students. $25(35.7 \%)$ participants were strongly disagreed that means they were not accepted their academic weaknesses as being femaleness. $17(27.1 \%)$ were disagreed with the idea of pessimism in education. Teachers were not frequently encouraged female students in English classroom to enhance their involvement.

$36(51.5 \%)$ responded they were strongly agreed and 18 $(25.7 \%)$ were agreed i.e. female students were affected by fear of their English teachers in the classroom. As it was shown that English teachers' were less likely encouraged female students, as a result the target students performed less in their interaction. Most of the time, English teachers were directed questions to male students than female students in the classroom as it was represented by large number of participants i.e. 37 $(53 \%)$.

$29(41.5 \%)$ of female students disagreed and $21(30 \%)$ were strongly disagreed concerning the chance given to their interaction. Therefore, English teachers were not focused in directing questions to female students in the classroom during English lesson rather than male counterparts. Concerning whether family background affected female students English classroom participation or not, $33(47 \%)$ of them agreed but insignificant number, $17(12.3 \%)$ of them were disagreed with this idea. From this we can generalize that their family backgrounds most likely affected their involvement in the classroom in English lesson.

Significant large numbers of respondents 23 (32.8\%) were strongly disagreed i.e. socio-cultural factors were not affected female students' classroom participation in English. The next largest number of participants, 20 (28.6\%) were undecided. Thus, we can see that this factor had not affected female students' participation in the classroom. Lastly, huge number of participants 30 (42.8\%) agreed that they had no interest in English subject matter so that they were not interacted in English.

Table.1 Socio-demographic characteristics

\begin{tabular}{|c|c|c|c|c|}
\hline \multirow[b]{2}{*}{ No. } & \multirow[b]{2}{*}{ Background } & & \multicolumn{2}{|c|}{ Participants } \\
\hline & & & No. & $\%$ \\
\hline \multirow[t]{3}{*}{1} & \multirow[t]{3}{*}{ Address } & Urban & 25 & 36 \\
\hline & & Rural & 45 & 64 \\
\hline & & Total & 70 & 100 \\
\hline \multirow{4}{*}{2} & \multirow{4}{*}{ Age } & $18-22$ & 19 & 27 \\
\hline & & $23-25$ & 42 & 60 \\
\hline & & Above 26 & 9 & 13 \\
\hline & & Total & 70 & 100 \\
\hline \multirow[t]{3}{*}{3} & \multirow[t]{3}{*}{ Marital status } & Married & 12 & 17 \\
\hline & & Single & 58 & 83 \\
\hline & & Total & 70 & 100 \\
\hline \multirow{4}{*}{4} & \multirow{4}{*}{ Religion } & Protestant & 30 & 43 \\
\hline & & Orthodox & 23 & 33 \\
\hline & & Islam & 17 & 24 \\
\hline & & Other & - & - \\
\hline \multirow[t]{4}{*}{5} & \multirow{4}{*}{$\begin{array}{c}\text { Family } \\
\text { Background }\end{array}$} & Total & 70 & 100 \\
\hline & & Literate & 26 & 37 \\
\hline & & Illiterate & 44 & 63 \\
\hline & & Total & 70 & 100 \\
\hline
\end{tabular}


Table.2 Factors that affect female students' classroom participation in English

\begin{tabular}{|c|c|c|c|c|c|c|c|c|c|c|c|}
\hline \multirow{3}{*}{ No } & \multirow{3}{*}{ Question Items } & \multicolumn{10}{|c|}{ Likert Scales } \\
\hline & & \multicolumn{2}{|c|}{5} & \multicolumn{2}{|c|}{4} & \multicolumn{2}{|c|}{3} & \multicolumn{2}{|c|}{2} & \multicolumn{2}{|c|}{1} \\
\hline & & No. & $\%$ & No. & $\%$ & No. & $\%$ & No. & $\%$ & No. & $\%$ \\
\hline 1 & $\begin{array}{l}\text { I confidently participate in English } \\
\text { classroom, high perception. }\end{array}$ & 6 & 8.6 & 7 & 10 & 5 & 7.2 & 28 & 40 & 24 & 34.2 \\
\hline 2 & $\begin{array}{l}\text { I have high classroom interaction in } \\
\text { English while being in same sex-group. }\end{array}$ & 12 & 17.1 & 30 & 42.9 & 9 & 12.9 & 4 & 5.7 & 15 & 21.4 \\
\hline 3 & $\begin{array}{l}\text { I have high classroom interaction in } \\
\text { English while being in mixed sex } \\
\text { group }\end{array}$ & 7 & 10 & 13 & 18.6 & 3 & 4.2 & 13 & 18.6 & 34 & 48.6 \\
\hline 4 & $\begin{array}{l}\text { Guidance and counseling helps me to } \\
\text { promote participation in English } \\
\text { classroom. }\end{array}$ & 14 & 20 & 27 & 38.5 & 11 & 15.7 & 13 & 18.6 & 5 & 7.2 \\
\hline 5 & $\begin{array}{l}\text { I equally participate with male counter } \\
\text { parts in English classroom. }\end{array}$ & 4 & 5.7 & 12 & 17.1 & 15 & 21.5 & 22 & 31.4 & 17 & 24.3 \\
\hline 6 & $\begin{array}{l}\text { I accept my academic weakness in } \\
\text { general and interaction in English } \\
\text { classroom in particular because of } \\
\text { being femaleness naturally, low } \\
\text { perception. }\end{array}$ & 4 & 5.7 & 16 & 22.9 & 6 & 8.6 & 19 & 27.1 & 25 & 35.7 \\
\hline 7 & $\begin{array}{l}\text { I am pessimistic in my education that } \\
\text { paves the way to low participation in } \\
\text { English classroom. }\end{array}$ & 12 & 17.1 & 18 & 25.7 & 10 & 14.3 & 17 & 24.3 & 13 & 18.6 \\
\hline 8 & $\begin{array}{l}\text { My English teacher encourages me } \\
\text { frequently in English classroom. }\end{array}$ & 10 & 14.3 & 18 & 25.7 & 11 & 15.7 & 29 & 41.4 & 2 & 2.9 \\
\hline 9 & $\begin{array}{l}\text { My English teacher encourages me } \\
\text { sometimes in English classroom }\end{array}$ & 21 & 30 & 30 & 42.9 & 13 & 18.6 & 5 & 7.1 & 1 & 1.4 \\
\hline 10 & $\begin{array}{l}\text { Fear of English teacher in the } \\
\text { classroom affects my participation. }\end{array}$ & 36 & 51.5 & 18 & 25.7 & 5 & 7.1 & 7 & 10 & 4 & 5.7 \\
\hline 11 & $\begin{array}{l}\text { Most of the time English teacher } \\
\text { directs questions to male students than } \\
\text { female students. }\end{array}$ & 37 & 53 & 12 & 17.1 & 4 & 5.7 & 14 & 20 & 3 & 4.2 \\
\hline 12 & $\begin{array}{l}\text { Most of the time English teacher } \\
\text { directs questions to female students } \\
\text { than male counterparts. }\end{array}$ & 4 & 5.7 & 1 & 1.4 & 15 & 21.4 & 29 & $\begin{array}{l}41 . \\
5\end{array}$ & 21 & 30 \\
\hline 13 & $\begin{array}{l}\text { My family background has affected } \\
\text { my classroom participation in the } \\
\text { classroom }\end{array}$ & 9 & 12.9 & 33 & 47 & 2 & 2.9 & 17 & $\begin{array}{l}24 . \\
3\end{array}$ & 9 & 12.9 \\
\hline 14 & $\begin{array}{l}\text { Socio-cultural factors } \text { (religion, } \\
\text { gender, etc. affected my } \\
\text { participation in English. }\end{array}$ & 7 & 10 & 2 & 2.9 & 20 & 28.6 & 18 & $\begin{array}{l}25 . \\
7\end{array}$ & 23 & 32.8 \\
\hline 15 & $\begin{array}{l}\text { I have no interest in English subject } \\
\text { matter in fact I do not communicate in } \\
\text { it }\end{array}$ & 10 & 14.3 & 30 & 42.8 & 9 & 12.9 & 14 & 20 & 7 & 10 \\
\hline
\end{tabular}

NB: $5=$ Strongly Agree, $4=$ Agree, $3=$ Undecided, $2=$ Disagree and $1=$ Strongly Disagree 


\section{Conclusion}

As it was clearly addressed in finding section, female students were not confidently participated in the classroom in English i.e. the extent of their participation was low. However, they were interacted well in same sex group arrangement. On the other hand, they were less likely took part in mixed sex group arrangement. Furthermore, they were tended to be dominated by male counterparts in the classroom. As findings shown above that guidance and counseling in the school played great role in contributing their classroom involvement as it was also seen in interview section. English teachers were not frequently encouraged female students to interact in English in the classroom as well as outside the classroom rather they sometimes or rarely encouraged female students' participation in the classroom. Very small number as it was seen in discussion section that female students replied that teachers encouraged their participation in English classroom. Teachers were not shown great attention to female students even they were most of the time directed questions to male students. Moreover, another factor that contributed to the low participation of female students in English classroom was fear of teachers, fear of making mistakes and fear of peers' especially male students. In addition, female students' family background i.e. whether their family was literate or illiterate, aware of education or unaware of education, low economic level or high economic level, etc. affected their learning in general and classroom participation in particular. Large number female respondents were replied as it was seen in analysis of questionnaire as well as interview that they were not interested in classroom participation in English. From English teachers' interview result it can be concluded that cultural and social factors negatively influenced female students' participation in the classroom. They scored low results in English subject matter. English teachers were not gave due attention to female students because they were not wanted to impose female students. Guidance and counseling had influential role in female students' classroom participation. Their families being literate or illiterate contributed in their classroom involvement in English to mean that literate one contributed positively and the vise-versa is true.

\section{Recommendations}

Based on the conclusion reached, the following recommendations were forwarded.
It is better if much consideration should be given to female students' involvement in education in general and classroom participation in English in particular. This is because as the researcher has seen the extent of participation, their classroom participation was low compared to male students in English. Most of the time English teachers gave chance to boys than girls as it was clearly depicted in conclusion section. So, the English teachers should give equal chance to female students as of male counter parts while asking question in the classroom. The stakeholders such as classroom teachers, principals, parent-teachers' councils, female students themselves, etc. are expected to make conducive atmospheres to the worst situations of female students involvement in English classroom. English teachers should arrange female students same sex group in the case of tutorial classes to increase their participation and to reduce fear of making mistakes letting them learning independently. English teachers should frequently encourage female students by giving advice, tutoring them in same sex arrangement, giving awareness, etc. to promote their confidence to interact in the classroom. As it was concluded that female students' family background affected their participation in classroom participation, school teachers (of English), principals and counseling expertise should give great attention in setting female students' minds to get prepared in communication in English in the classroom. Students' parents should be aware of their daughters' learning by giving them time to study, to improve themselves, advise them, to promote their confidence.

\section{References}

Anderson, H. (1993). Successful Training Practice: A Manager's Guide to Personnel Development: Oxford UK: Blackwell Business Publishers

Bean, J. C. (1996). Engaging Ideas: The Professor's Guide to Integrating Writing, Critical Thinking and Active Learning in the Classroom: San Francisco: Jossey-Bass

Bunch, C. (2000). "Global Feminism, Human Rights and Sexual Violence." In Proceedings from the First Annual Women's Policy Research Conference, May 19, 1989, ed. Institute for Women's Policy Research. Washington, D.C.: Institute for Women's Policy Research.

Chianu, E. (1983). Corporal Punishment in Primary and Secondary School: Asaba: Publishers Limited Ensell Books

Davis, B. G. (1993). Tools for teaching (2nd.ed.): San Francisco: Jossey-Bass. 
Diller A. and Housten B. (1996). The Gender Question in Education: Theory, Pedagogy and Politics

Ellis, N.C. (1996). Sequencing in SLA: Phonological memory, chunking, and points of order. Studies in Second Language Acquisition 18 (1):91-126.

Ellis, G. (1996). How culturally appropriate is the communicative approach? ELT Journal, 50(3), 213218

Freeman L. 2000. Techniques and Principles in Language Teaching: Second Edition: Oxford: Oxford University Press

Gutheridge (1992). Gender Roles in Development Project: Kumaria Hendrikz E (1986). Introduction to Education Psychology: London: Macmillan.

Holmes, J. (1994). Gendered Talk at Work. Oxford: Blackwell.

Johnson, D. W., and Johnson, F. P. (1991.). Joining Together: Group Theory and Group Skills. (4th ed.) Englewood Cliffs, N.J.: Prentice Hall

Karim, K. M. R. (2004). Teachers' perceptions, attitudes, and expectations about communicative Language teaching (CLT) in post-secondary education in Bangladesh: Unpublished Master thesis, University of Victoria

Liao, W. W. (2006). High School Teachers' Belief and Implementation of CLT in Taiwan: Unpublished master thesis, National Taiwan Normal University.

Li, D. (1998). 'It's always more difficult than you plan and imagine': Teachers' Perceived Difficulties in introducing the communicative approach in South Korea, TESOL Quarterly 32 (4), 677-703.

Liao, X. (2000). How communicative language teaching became acceptable in secondary Schools in China: The Internet TESL Journal, 6 (10). Retrieved December14, 2000, from the World Wide Web: http://www.aitech.ac.jp/ iteslj/Articles /LiaoCLTinChina.html.

Lee, J. H. (2013). Investigating Age in the Use of L1 or English-Only Instruction: Vocabulary Acquisition by Korean EFL Learners: The Modern Language Journal, 97(4), 887-901.

Littlewood, W. (2007). Communicative and Task-based language teaching in East Asian Classrooms: Language Teaching 40 (3), 243-249.

\section{How to cite this article:}

Addisu Bogale Shago. 2019. Difficulties of Female Students in Classroom Participation in English at Areka Preparatory School, Wolaita Zone, Southern Ethiopia, 2019. Int.J.Curr.Res.Aca.Rev. 7(4), 76-90.

doi: https://doi.org/10.20546/ijcrar.2019.704.009
McKeachie, W. J. 1986.Teaching Tips: A Guidebook for the Beginning College Professor. ( $8^{\text {th }}$ ed.) Lexington, Mass.: D. C. Heath

Nunan, D. (2003). The impact of English as a Global Language on Educational Policies and Practices in the Asian-Pacific Region: TESOL Quarterly, 37(4), 589-613.

Odaga (1995). Girls and School in Sub-Saharan: From analysis to Action: Washington DC, World Bank

Richards, J. C., and Rodgers, T. S. (1986). Approaches and methods in language teaching: Cambridge: Cambridge University Press.

Smith, B. (2003). Computer-mediated negotiated interaction: An expanded model. The Modern Language Journal, 87(i), 38-57.

Spolsky B. (1989). Conditions for Second Language Learning: Oxford: Oxford University Press, Pp. Vii $+272$

Sunderland, J. (1994). Exploring gender: questions and implications for English Language Education: Hemel Hempstead: Prentice Hall

Seyoum Tefera (1988). The Education of Women in Ethiopia: A Missing Peace in development Puzzle: The Ethiopian Journal of Vol. 10 No.1

Takanashi, Y. (2004). TEFL and communication styles in Japanese culture: Language, Culture and Curriculum, 17(1), 1-14.

Tirufat Bekele (1996). Gender in Ethiopia: Quality of education in Ethiopia Vision for the $21^{\text {st }}$ Century: AAU, Printing press.

Tsui, T. H. (2007). Taiwanese educators' perspective on the implementation of the new English Education policy: Unpublished doctoral dissertation, Alliant International University.

Wana L. and Tsion D. (1994). Educational Wastage: The Case of Female Students in Selected Primary and Secondary Schools of Ethiopia, IDR

Welty, W. M. (1989). Discussion Method Teaching: How to make it Work. Change, 21, 40-49.

$\mathrm{Yu}, \mathrm{L}$. (2001). Communicative language teaching in China: Progress and resistance: TESOL Quarterly, 35(1), 194-179. 


\section{Appendices \\ Appendix A. Students Questionnaire \\ Wolaia Sodo University \\ College of Social Science and Humanities \\ Department of English Language and Literature \\ Questionnaires to be filled by Female Student Participants}

Dear Student: The purpose of the questionnaire is to see Difficulties of Female Students in Classroom Participation in English at Areka Preparatory School, Wolaita Zone, Southern Ethiopia.Therefore, for this research is to be valid, your cooperation has great value.

\section{Reminders:}

Thank You in Advance!

* Don't write your name on the questionnaire.

* Put an "X" mark only in the table under your choice.

* For open-ended question, i.e. questions 17 and 18, write your answer/opinion on the space provided.

\section{Personal Information:}

1. Address: Urban $\square$ Rural $\square$

2. Age: $18-20 \square 21-25 \square 26$ and above

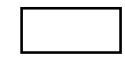

3. Marital Status: Married

Unmarried

4. Religion: Protestant

Orthodox

Islam

Other

5. Family Background: Literate

Illiterate

Questionnaires to be filled by Female Student Participants

NB: 5 = Strongly Agree, 4 = Agree, 3 = Undecided, $2=$ Disagree and 1 = Strongly Disagree

\begin{tabular}{|c|c|c|c|c|c|c|c|c|c|c|c|}
\hline \multirow{3}{*}{ No. } & \multirow{3}{*}{ Question Items } & \multicolumn{8}{|c|}{ Likert Scales } & & \\
\hline & & \multicolumn{2}{|l|}{5} & \multicolumn{2}{|c|}{4} & \multicolumn{2}{|l|}{3} & \multicolumn{2}{|l|}{2} & \multicolumn{2}{|l|}{1} \\
\hline & & No. & $\%$ & No. & $\%$ & No. & $\%$ & No. & $\%$ & No. & $\%$ \\
\hline 1 & $\begin{array}{l}\text { I confidently participate in English } \\
\text { classroom, high perception. }\end{array}$ & & & & & & & & & & \\
\hline 2 & $\begin{array}{l}\text { I have high classroom interaction in } \\
\text { English while being in same sex- } \\
\text { group. }\end{array}$ & & & & & & & & & & \\
\hline 3 & $\begin{array}{l}\text { I have high classroom interaction in } \\
\text { English while being in mixed sex } \\
\text { group }\end{array}$ & & & & & & & & & & \\
\hline 4 & $\begin{array}{l}\text { Guidance and counseling helps me to } \\
\text { promote participation in English } \\
\text { classroom. }\end{array}$ & & & & & & & & & & \\
\hline 5 & $\begin{array}{l}\text { I equally participate with male } \\
\text { counter parts in English classroom. }\end{array}$ & & & & & & & & & & \\
\hline
\end{tabular}




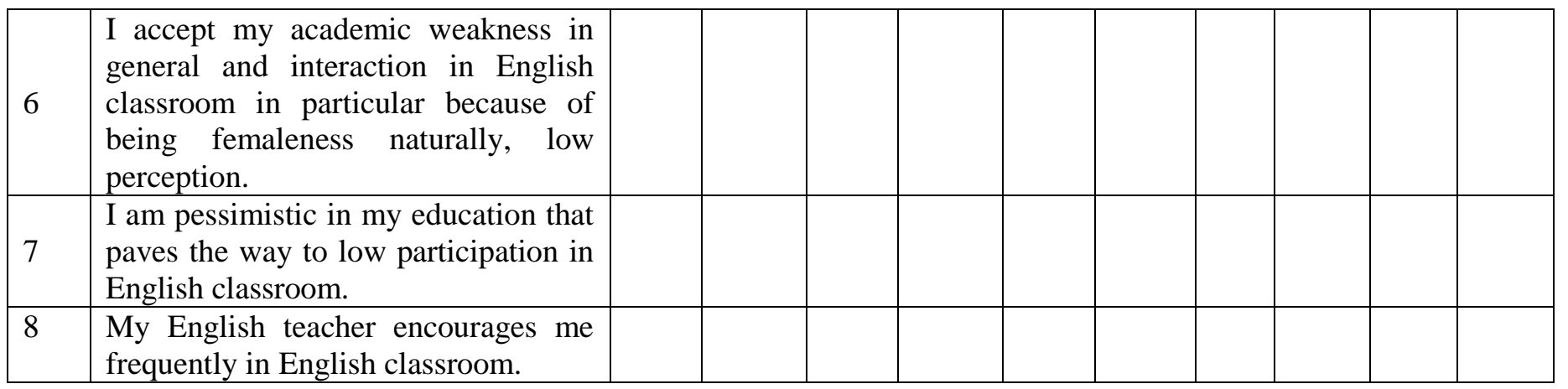

Questionnaires to be filled by Female Student Participants

NB: 5 = Strongly Agree, 4 = Agree, 3 = Undecided, 2 = Disagree and 1 = Strongly Disagree

\begin{tabular}{|c|c|c|c|c|c|c|c|c|c|c|c|}
\hline \multirow{3}{*}{ No. } & \multirow{3}{*}{ Question Items } & \multicolumn{10}{|c|}{ Likert Scale } \\
\hline & & \multicolumn{2}{|l|}{5} & \multicolumn{2}{|l|}{4} & \multicolumn{2}{|l|}{3} & \multicolumn{2}{|l|}{2} & \multicolumn{2}{|l|}{1} \\
\hline & & No. & $\%$ & No. & $\%$ & No. & $\%$ & No. & $\%$ & No. & $\%$ \\
\hline 9 & $\begin{array}{l}\text { My English teacher encourages me } \\
\text { sometimes in English classroom }\end{array}$ & & & & & & & & & & \\
\hline 10 & $\begin{array}{l}\text { Fear of English teacher in the } \\
\text { classroom affects my participation. }\end{array}$ & & & & & & & & & & \\
\hline 11 & $\begin{array}{l}\text { Most of the time English teacher } \\
\text { directs questions to male students than } \\
\text { female students. }\end{array}$ & & & & & & & & & & \\
\hline 12 & $\begin{array}{l}\text { Most of the time English teacher } \\
\text { directs questions to female students } \\
\text { than male counterparts. }\end{array}$ & & & & & & & & & & \\
\hline 13 & $\begin{array}{l}\text { My family background has affected } \\
\text { my classroom participation in the } \\
\text { classroom }\end{array}$ & & & & & & & & & & \\
\hline 14 & 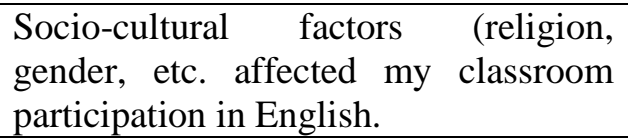 & & & & & & & & & & \\
\hline 15 & $\begin{array}{l}\text { I have no interest in English subject } \\
\text { matter in fact I do not communicate in } \\
\text { it }\end{array}$ & & & & & & & & & & \\
\hline
\end{tabular}

\section{Open-ended Questions}

16. To what extent do you participate in English in male dominated classroom? Explain in detail.

17. To what extent do your perception about yourself promoted your participation English classroom? Explain in detail.

Wolaia Sodo University Appendix B. Teachers Interview 


\section{Wolaita Sodo University \\ College of Social Science and Humanities \\ Department of English Language and Literature \\ II. Teachers' Interview}

Dear Teachers: The purpose of the is to see 'Difficulties of Female Students in Classroom Participation in English at Areka Preparatory School, Wolaita Zone, Southern Ethiopia.' Therefore, your cooperation contributes my research to valid.

\section{Personal Information:}

Thank You in Advance!

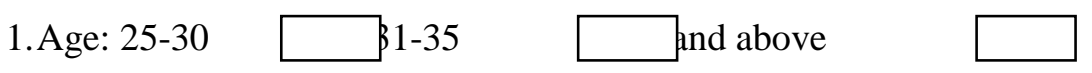

2.Marital Status: Married

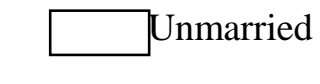

3. Religion: Protestant
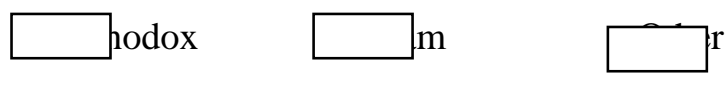

\section{Interview Questions}

1. Do you think socio-cultural factors are obstacles for female students' classroom participation in English? If so how does it affect their participation in English classroom?

2. Do you encourage female students to participate in the classroom in English? If yes how do you do so?

3. Do you agree the religious factor affects female students' classroom participation in English? If you agree, in what condition does it affect their participation?

4. Do you agree guidance and counseling in the school has role in female students' classroom participation?

5. Explain how family's literacy and illiteracy affect female students' classroom participation in English. 